\title{
Heavy Metal Ions Levels and Related Physicochemical Parameters in Soils in The Vicinity of a Paper Industry Location in Nahan Area of Himachal Pradesh
}

Mamta Chhabra Sharma ${ }^{1 *}$, Shalini Baxi ${ }^{1}$, Kaushal K Sharma ${ }^{2}$, Manpreet Singh ${ }^{1}$ and Shashank Patel ${ }^{2}$

${ }^{1}$ Department of Chemistry, Kirori Mal College, University of Delhi, India

${ }^{2}$ Department of Geography, Kirori Mal College, University of Delhi, India

\begin{abstract}
Background concentrations of heavy metal ions concentration in soils are important due to their pollution potential and toxic effect of these elements on human health and the environment. These metals in soils in the vicinity of paper manufacturing industry were studied. Concentrations of these heavy metal ions (e.g., $\mathrm{Pb}, \mathrm{Zn}, \mathrm{Cd}, \mathrm{Cr}$ ) were analyzed using Atomic Absorption Spectrophotometer (A.A.S). The findings revealed that the average concentrations of these metals in soil samples were three to ten times higher than the permissible limits. Levels of these trace metals in the industrial environment were generally high, indicating that the activities of paper industry and associated processes contributed to the observed higher levels of trace metals in the industry environment. The aim of this study was to determine the levels of these heavy metals in the soil and to ascertain the pollution status.
\end{abstract}

Keywords: Heavy metals; Soils; Environment; Paper manufacturing industry; Pollution

\section{Introduction}

Industrialization is on the increase and so is the environmental pollution due to emissions and waste generated from these industries. The industrial pollution due to its nature has potential to cause irreversible reactions in the environment and hence is posing a major threat to sustainable development. Since the carrying capacity of the environment is not unlimited and some areas or ecosystems are more susceptible to adverse environmental impacts than others, the unplanned and haphazard location of industries might substantially increase the risk to the environment. Shiwalik belt in Himachal Pradesh has come up in a big way in industrial development. Different types of industries have been established in the recent past. Shiwalik region is very fragile ecologically and environmentally. This zone is transition with Middle Himalayas in the north and fertile plains of Haryana and Punjab. Many industrialists from Punjab and Haryana are attracted to establish industries in this zone due to dust free environment. Water quality is has been good and many streams pass through this zone. Forest cover is adequate. Although the availability of minerals is low, therefore most of the raw material for the industries come from outside in heavy truck. Industrial pollution range from chemical, air and water. Industries are located at Baddi, Barotiwala, Parwanoo, Kala Amb, Paonta Sahib, Mehatpur, Tahliwal, Amb, Sansarpur Terrace and Golthai. Soils differ across the landscape, as each site is characterized by unique trace element concentrations based on parent material of soil and other soil-forming factors that may have supplemented or removed these elements from the soil. High background concentrations of heavy metal ions, whether natural or anthropogenic, could result in mobility and release into surface and subsurface waters and subsequently their incorporation into the food chain. Soil factors such as $\mathrm{pH}$ and conductivity are influenced and also influence the quantity of these heavy metals available for mobilization and release or sorption in a soil. Several studies document gradual increases in the trace element contents of agricultural and forested soils due to waste discharge and effluents from industries [1-3]. While essential in small quantities for plant growth, micronutrients like zinc $(\mathrm{Zn})$ can be poisonous at high concentrations in the soil. Some elements not known to be essential to plant growth, such as arsenic (As), cadmium (Cd), chromium (Cr), and lead $(\mathrm{Pb})$ are also toxic at high concentrations or under certain environmental conditions in the soil. The extent of soil pollution by heavy metals and base metal ions some of which are soil micronutrients is very alarming in the vicinity of a paper mill in Nahan Tehsil of Himachal Pradesh. It has been observed that with industrialization of this fragile ecosystem the quality of the environment has lowered down $[4,5]$.

Concentration of these heavy metals in soils is associated with geometrical cycles and biological processes and could be greatly influenced by such industrial activities. In the food chain primary producers i.e., plants are capable of absorbing these metals from the soil $[6,7]$. These metals each into the soil when they undergo chemical reactions and could come in direct contact with roots of plants [8]. When these plants in the form of vegetables, are consumed by man, trace metals become bioaccumulated and eventually result in several ailments which may subsequently cause death [9]. In some cases plants accumulate some of these metals which are not injurious to them, but may be poisonous to animals grazing on the plants [10]. The paper mill was of concern because of its location close to where rural populace settlement. The distance of the paper industry to the water source of the community is a cause of worry [11].

Some of the wastes emanating from paper production unit are spread over some parts of the environment particularly on water-logged soil. Heavy metals present in the waste may therefore accumulate in the soil environment. Hence, the soils in this environment are assumed to be polluted with heavy metals. This investigation is therefore to assess

*Corresponding author: Mamta Chhabra Sharma, Department of Chemistry Kirori Mal College, University of Delhi, India, Tel: 9350547156; E-mail: mamta610@gmail.com

Received June 18, 2014; Accepted July 29, 2014; Published July 31, 2014

Citation: Sharma MC, Baxi S, Sharma KK, Singh M, Patel S (2014) Heavy Metal lons Levels and Related Physicochemical Parameters in Soils in The Vicinity of a Paper Industry Location in Nahan Area of Himachal Pradesh. J Environ Anal Toxicol 4: 236. doi: 10.4172/2161-0525.1000236

Copyright: (c) 2014 Sharma MC, et al. This is an open-access article distributed under the terms of the Creative Commons Attribution License, which permits unrestricted use, distribution, and reproduction in any medium, provided the original author and source are credited. 
the trace metal levels in soil within the Paper industry environment. Again, heavy metals discharged into our environment including their distribution, reaction in the ecosystem and subsequent uptake and distribution in soils are of great concern for human health [12]. Specifically, the aims of the study are to determine the levels of some heavy metals in soil within the Paper industry environment, to ascertain the pollution standing and the effect of the trace metals in the environment [13].

\section{Materials and Methods}

\section{Study area}

Paper Mill was one of the major Paper producing industries in the Nahan Tehsil of Simaur district of Himachal Pradesh. (The name of the mill has not been disclosed due to publishing ethics). Our study was divided in three zones. This mill was situated in the first zone (Figure 1).

\section{Soil sample collection}

Soil sampling was carried out by collecting portions of soil using a soil auger of length $15 \mathrm{~cm}$ at each location. The samples were put into polyethylene bags, labeled and taken to the laboratory for pre-treatment and analysis. Sampling was carried out within this environment from three different locations for summers and winters (June and January). Soils samples were collected in triplicate from each location. Control samples were also collected about $10 \mathrm{~km}$ away from the industry.

\section{Preparation of soil samples, treatment and chemical analysis}

Samples were air-dried at normal laboratory temperature. Soil samples were ground using pestle mortar and sieved to pass through 2 $\mathrm{mm}$ sieve and stored safely for chemical analysis.

\section{Heavy metal ions concentrations}

The samples were then digested using the microwave digestion procedure [14] for total $\mathrm{Pb}$ concentration using Scientific microwave

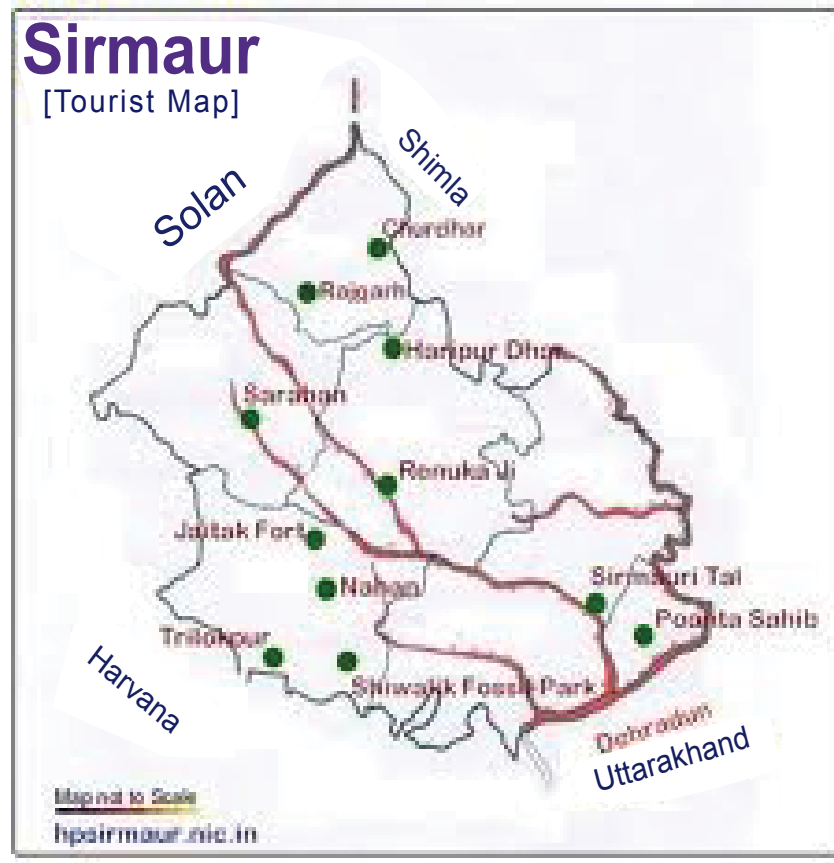

Figure 1: Study area of major paper producing industries
Anton Paar Multiwave 3000. The clean soil sample was collected from region $10 \mathrm{~km}$ away from industry. Concentrations of heavy metal ions, in the extracts were analyzed with AAS (acetylene air flame) (Perking Elmer A Analyst -100) with addition calibration. Data presented in the investigations is an average of twelve replicates with a standard deviation.

\section{Electrochemical properties}

Electric conductivity (EC) and $\mathrm{pH}$ were measured in water suspensions and in $0.01 \mathrm{M} \mathrm{CaCl}_{2}$. (Elico CM 180 and Elico LI 127). $\mathrm{pH}$ of the soil is one of the main parameter for determining the extent of pollution. So we prepared the standard solution of soil by weighing $20 \mathrm{~g}$ in $100 \mathrm{~mL}$ of the water as described in methods approved by NPDES. Solution prepared was kept on the magnetic stirrer for about 2 hours prior to each reading. $\mathrm{pH}$ meter was used for this parameter. Set of three readings were obtained. Conductance was calculated by preparing standard solutions of the samples by the methods approved by NPDES. Conductometer was used for this purpose. Set of three reading was obtained and samples were kept for constant stirring on the magnetic stirrer for almost 2 hour prior to each reading [15].

\section{Analysis of water samples}

- Water samples were treated by the $\mathrm{pH}$ meter to get the set of three reading for $\mathrm{pH}$ of the samples

- Water samples were treated by the conductometer to get the set of three reading for conductance of the samples

- Then the DO was calculated by using the apparatus Dissolved Oxygen calculator meter

\section{Methodology for primary survey}

Looking at the side effect of the industrial pollution on environment and human health a questionnaire was framed which helped in taking inputs from the local villagers about their assessment of the environmental degradation. Primary field survey concerning geographical aspects was carried out to evolve critical interaction areas, specific area needs, ecosystem needs.

\section{Results and Discussion}

Areas near Rapur Jattan, Patti Nath villages, having paper industries, indicate higher levels of lead $\mathrm{Pb}(\mathrm{II})$, chromium $\mathrm{Cr}$ (II) and cadmium Cd(II). For good plant growth $\mathrm{pH}$ between 5.5 and 7.0 is suitable. However, in these polluted terrains, $\mathrm{pH}$ is well above 8 i.e., the soil is alkaline [16]. The analysis results of samples collected in different time are shown in Tables 1-4 during summer and winter. Tables show the mean values of the concentration of metals.

The concentrations of metals in soils at the site and the control site indicate that there is an evidence of relative increase in the concentrations of heavy metals in soils at the site compared to the control site. The metals considered in this study include the metals which are micronutrients such as zinc, and the non-essential/toxic trace metals which are toxic to plant when present in the soil at concentrations above tolerance level. The latter class of trace metals includes lead and cadmium. Based on the results (Tables 1-4), there was a significant difference between the concentrations of all the metals at the Paper manufacturing industrial site and the control site in all the samples [17].

The natural range for the concentration of zinc in soil is $5 \mathrm{ppm}$. The mean level of $\mathrm{Zn}$ in soil samples of the study area five times higher 
Citation: Sharma MC, Baxi S, Sharma KK, Singh M, Patel S (2014) Heavy Metal lons Levels and Related Physicochemical Parameters in Soils in The Vicinity of a Paper Industry Location in Nahan Area of Himachal Pradesh. J Environ Anal Toxicol 4: 236. doi: 10.4172/2161-0525.1000236

Page 3 of 7

than the permissible level of $\mathrm{Zn}$ in drinking water. Zinc although being an essential trace element in low concentration, is toxic in high concentration [18]. Assimilation of Zinc in excess of $12 \mathrm{mg}$ per day may be a source of lung disturbance [19].

The mean concentrations of lead in the soil samples are six to seven times higher than the permissible concentration is between 0.05 $0.1 \mathrm{ppm}$. Presence of lead in this environment may have been due to

\begin{tabular}{|c|c|c|c|c|c|}
\hline Agencies & Lead & Cadmium & Chromium & Arsenic & Zinc \\
\hline ISI & 0.1 & 0.01 & 0.05 & 0.05 & 5.0 \\
\hline WHO & 0.05 & 0.005 & - & 0.05 & 5.0 \\
\hline USEPA & - & 0.005 & 0.1 & 0.05 & - \\
\hline CPCB & NR & NR & NR & NR & 15 \\
\hline
\end{tabular}

*: No Relaxation

Table 1: Permissible limits of heavy metals by different agencies (ppm) in drinking water. automobile emission and industrial emission [20]. Chronic exposure to lead can lead to chronic lead poisoning, which will result in memory loss and restlessness. Lead has been found to inhibit enzymatic activity [21]. The pollution of soil by lead is a serious problem that has been given much attention by environmental chemists. This is due to the fact lead is a accumulative pollutant [22] and the unceasing dumping of lead containing waste into the environment should be discouraged.

The natural permissible limit of cadmium in soil is $0.005 \mathrm{ppm}$. The mean concentration of cadmium in the soil samples of the study area is ten times higher than the permissible limit of cadmium in soil. The soil is therefore considered to be polluted by cadmium. Exposure to high cadmium levels may result in ailment known as osteoporosis [23]. Cadmium is regarded as the most hazardous trace element and its poisoning may cause damage to kidney and heart and prolonged exposure results in loss of calcium from the bone [24]. Toxicological

\begin{tabular}{|c|c|c|c|c|c|c|c|c|}
\hline Sample code & $\mathrm{Zn}$ & $\mathrm{Ca}$ & $\mathrm{Cr}$ & Cd & $\mathrm{Na}$ & $\mathbf{K}$ & $\mathrm{Pb}$ & As \\
\hline W2013HP1001W & 3.6845 & 33.952 & 0.0022 & 0.0105 & 4.2437 & 1.5845 & 0.2381 & 0.0341 \\
\hline W2013HP1002W & 0.844 & 33.0065 & 0.0011 & 0.0026 & 4.7783 & 1.4693 & 0.2313 & 0.5622 \\
\hline W2013HP1003W & 1.266 & 33.0507 & 0.0086 & 0.0184 & 3.5052 & 0.9624 & 0.2789 & 0.5865 \\
\hline W2013HP1004W & 0.0586 & 9.0763 & 0.3403 & 0.0062 & 1.1753 & 4.9026 & 0.2728 & 0.2671 \\
\hline W2013HP1005W & 18.8284 & 30.7915 & 0.0129 & 0.0552 & 5.4188 & 1.1943 & 0.3674 & 0.5243 \\
\hline W2013HP1006W & 2.6214 & 30.2849 & 0.002 & 0.021 & 5.2405 & 1.99 & 0.6463 & 0.519 \\
\hline W2013HP1007W & 13.2205 & 32.7841 & 0.0119 & 0.0893 & 2.8054 & 0.8246 & 0.2585 & 0.1502 \\
\hline W2013HP1008W & 2.9785 & 32.5753 & 0.0108 & 0.0105 & 2.6662 & 0.9653 & 0.034 & 0.1411 \\
\hline W2013HP1009W** & 1.1605 & 29.229 & 0.002 & 0.0158 & 2.8503 & 1.0948 & 0.313 & 0.6017 \\
\hline
\end{tabular}

**The samples are coded as follows

S/W-soil/water

1/2/3-zone number 2012/2013-year of sampling 005-sample number,
HP-Himachal Pradesh

S/W-summer/winter

Table 2: Concentration of metal ions in water samples from different zones during winter season.

\begin{tabular}{|c|c|c|c|c|c|c|c|c|c|}
\hline Sample coding & $\mathrm{Pb}$ & As & Mg & $\mathrm{Na}$ & $\mathrm{Zn}$ & Cd & $\mathbf{K}$ & $\mathrm{Ca}$ & $\mathrm{Cr}$ \\
\hline S2012HP1005S & 3.069 & 1.0925 & 472.856 & 9.981 & 2.0545 & 0.1195 & 10.9255 & 9.293 & 5.4455 \\
\hline S2012HP1009S & 0.171 & 0.474 & 464.444 & 2.5 & 2.3995 & 0.855 & 8.3075 & 6.3915 & 3.063 \\
\hline S2012HP2005S & 0 & 0.33 & 452.9685 & 15.638 & 2.047 & 0.0885 & 15.784 & 36.0595 & 0 \\
\hline S2012HP2006S & 2.643 & 2.3485 & 483.602 & 4.587 & 3.935 & 0.2435 & 15.0705 & 37.716 & 2.3825 \\
\hline S2012HP2013S & 0.512 & 0.903 & 409.1325 & 2.89 & 2.0795 & 0.031 & 8.1505 & 3.358 & 70.1115 \\
\hline S2012HP2016S & 3.154 & 0.493 & 491.188 & 4.516 & 3.609 & 0.226 & 11.7835 & 32.0315 & 0.3405 \\
\hline S2012HP2024S & 0 & 0.641 & 458.2685 & 4.4245 & 1.374 & 0.1285 & 7.957 & 11.811 & 29.61 \\
\hline S2012HP3005S & 0 & 3.05 & 498.895 & 6.0915 & 1.407 & 0.0355 & 17.083 & 36.214 & 12.933 \\
\hline S2012HP3011S & 8.184 & 0.5655 & 484.2585 & 6.278 & 2.181 & 0.2525 & 13.2715 & 35.61 & 19.4 \\
\hline S2012HP3012S & 0 & 1.0775 & 479.226 & 5.8765 & 6.1965 & 0.1285 & 14.1955 & 43.784 & 18.0385 \\
\hline S2012HP3013S & 0 & 0.1405 & 475.895 & 4.5805 & 2.691 & 0.0485 & 10.9845 & 42.3555 & 217.141 \\
\hline
\end{tabular}

Table 3: Concentration of metal ions in soil samples from different sampling points during summer season.

\begin{tabular}{|c|c|c|c|c|c|c|c|c|c|}
\hline Sample coding & $\mathrm{Pb}$ & As & Mg & $\mathrm{Na}$ & Zn & Cd & $\mathbf{K}$ & $\mathrm{Ca}$ & $\mathrm{Cr}$ \\
\hline S2013HP2001W & 0 & 0.0795 & 479.469 & 8.5885 & 9.378 & 0.071 & 12.5605 & 1.5905 & 22.1225 \\
\hline S2013HP2002W & 0 & 2.686 & 404.732 & 4.7565 & 2.4535 & 0.0385 & 9.5035 & 2.2605 & 2.042 \\
\hline S2013HP2003W & 0 & 2.4165 & 455.448 & 3.9715 & 0.8355 & 0.133 & 6.0525 & 1.1635 & 2.3825 \\
\hline S2013HP2004W & 0.767 & 1.6655 & 478.6425 & 4.7395 & 1.1575 & 1.178 & 8.386 & 0.8835 & 2.723 \\
\hline S2013HP2005W & 0.853 & 0.554 & 480.5875 & 6.503 & 3.195 & 0.04 & 13.2225 & 29.911 & 10.5505 \\
\hline S2013HP2006W & 0 & 2.91 & 479.08 & 5.0605 & 1.397 & 0.837 & 20.3875 & 8.144 & 148.0505 \\
\hline S2013HP2007W & 152.9 & 0.99 & 499.381 & 10.211 & 17.436 & 0.226 & 7.5305 & 36.8475 & 37.438 \\
\hline S2013HP2008W & 1.876 & 1.5905 & 481.268 & 3.965 & 2.478 & 0.0045 & 7.317 & 4.278 & 3.063 \\
\hline S2013HP2009W & 0.938 & 0.6185 & 490.118 & 3.7715 & 0.9815 & 0.0885 & 5.3045 & 75.587 & 108.5705 \\
\hline S2013HP2010W & 1.194 & 3.111 & 466.486 & 3.156 & 1.6335 & 0.009 & 4.3535 & 73.8785 & 43.224 \\
\hline S2013HP2011W & 0 & 0.7775 & 435.6335 & 4.2645 & 1.0025 & 0.022 & 2.9365 & 72.9585 & 2.723 \\
\hline S2013HP2012W & 1.876 & 1.5705 & 449.37 & 2.186 & 0.9295 & 0.0795 & 6.278 & 0.9055 & 110.6125 \\
\hline
\end{tabular}

Table 4: Concentration of metal ions in soil samples from different areas during winter season. 
Citation: Sharma MC, Baxi S, Sharma KK, Singh M, Patel S (2014) Heavy Metal lons Levels and Related Physicochemical Parameters in Soils in The Vicinity of a Paper Industry Location in Nahan Area of Himachal Pradesh. J Environ Anal Toxicol 4: 236. doi: 10.4172/2161-0525.1000236

Page 4 of 7

properties of cadmium come from its chemical similarity to zinc, an essential micronutrient for plants, animals and humans.

The mean concentrations of chromium in the soil samples are six times than the permissible $0.05 \mathrm{ppm}$ [25]. Exposure to chromium has been found to cause dermatitis [26], perforation of nasal septa and kidney damage among other diseases [21].

In Rapur Jattan village of Nahan Tehsil, due to chronic exposures of pollutants, slowly the air and water pollution is manifesting itself in various layers and dimensions. Survey studies have indicated a definite correlation in pollution levels and the type of diseases occurring in this area. New skin ailments have come up in that area. No such skin diseases were existing before 2000 and now nearly $60 \%$ of the respondents complained of the burning sensation and decolouration of skin. $30-35 \%$ of people are suffering from some or the other lung ailment be it asthma, lung problems, occasional ulceration of nasal passages, cough, or shortness of breath which were earlier non-existent. Other related problems sleeplessness, irritability, loss of appetite or chest pain are due to these polluted effluents. According to majority of respondents, due to lack of adequate health facilities, proper diagnosis and treatment is not available. Post 2000 cardiovascular diseases are also coming in higher numbers. $70 \%$ of the people interviewed are anemic. Local residents Mr Ranveer Singh and Mohammad Yami (Gram Pradhan) informed that around 8 to nine people have died of cancer in the recent past related to lungs. Life expectancy of the animals (pet and wild) has decreased considerably as majority of them directly depend on untreated effluents for drinking etc. The annual output of the mango crop of the area has reduced to much less than the average. The seasonal Rabi crop fails now to meet the basic requirement. A lot of animals and birds are at the verge of extinction as reported by respondents as we can see in $34 \%$ area a common house sparrow is difficult to be seen by villagers same as in case of vultures, eagles and many more. Plight of the villgers was reported in the print media also (Mail Today, July, 2013)

Decreasing groundwater level is due to excessive utilization in industries and contaminated surface water due to hazardous industrial waste disposal are major causes. Depth of water near industrial area is less whereas it is exceptionally much deeper in the areas considerably away from the industries. People living nearly $3 \mathrm{~km}$ in the radius of industries are majorly affected by the industries. Industrialization has affected almost all the parts of the environment, health, water bodies, vegetation and many other species living there.

Following points/indicators explain the effects of Industrialization in detail: The facts and Figures 2-9 in these points are based on the survey done on villagers.

- Condition of general available water is still better but surface water is worst affected.

- Water is affected in two ways, firstly ground water level is

Dissolved Oxygen

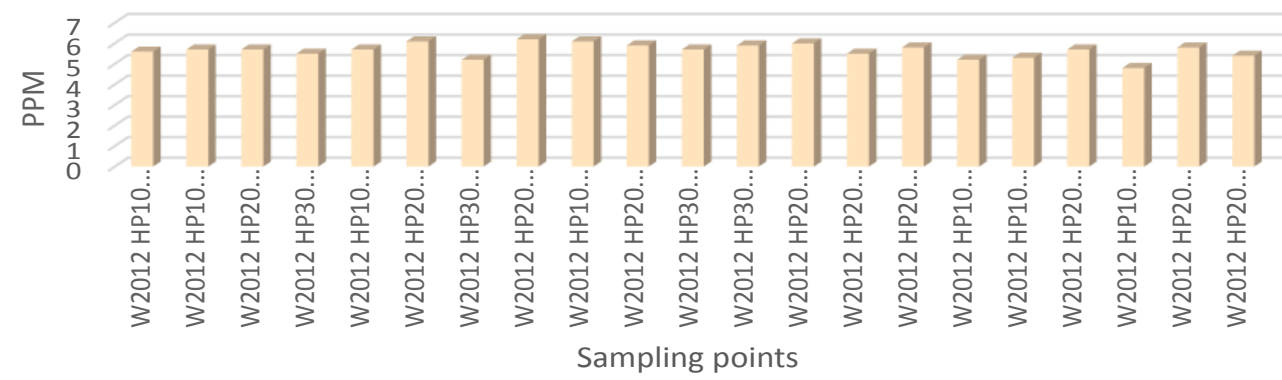

Figure 2: Dissolved Oxygen of water samples collected from different sampling points during summers.

\section{pH of water samples}

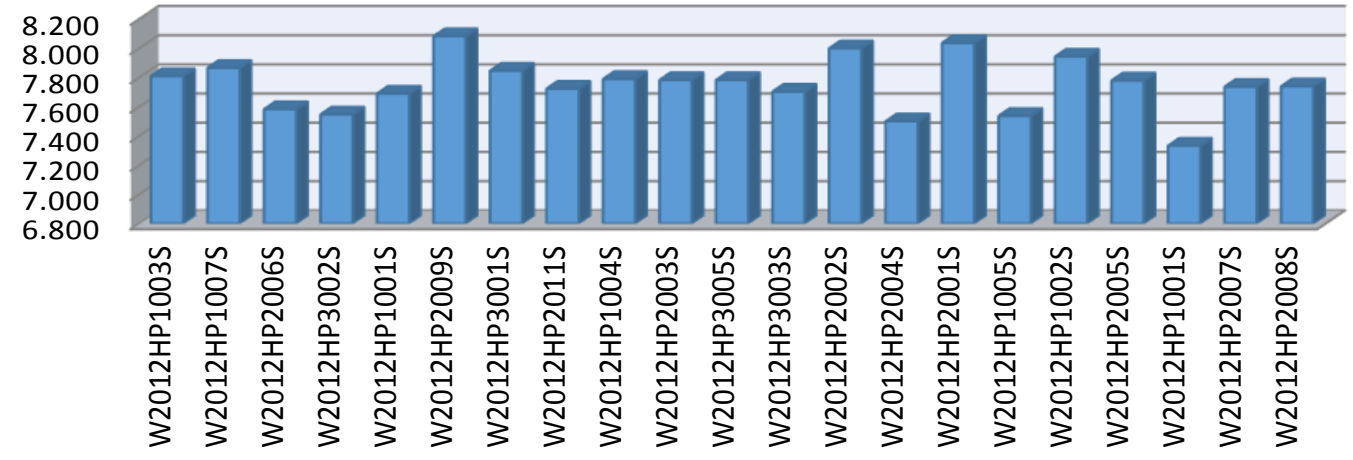

Figure 3: $\mathrm{pH}$ of water samples collected from different sampling points during summers. 


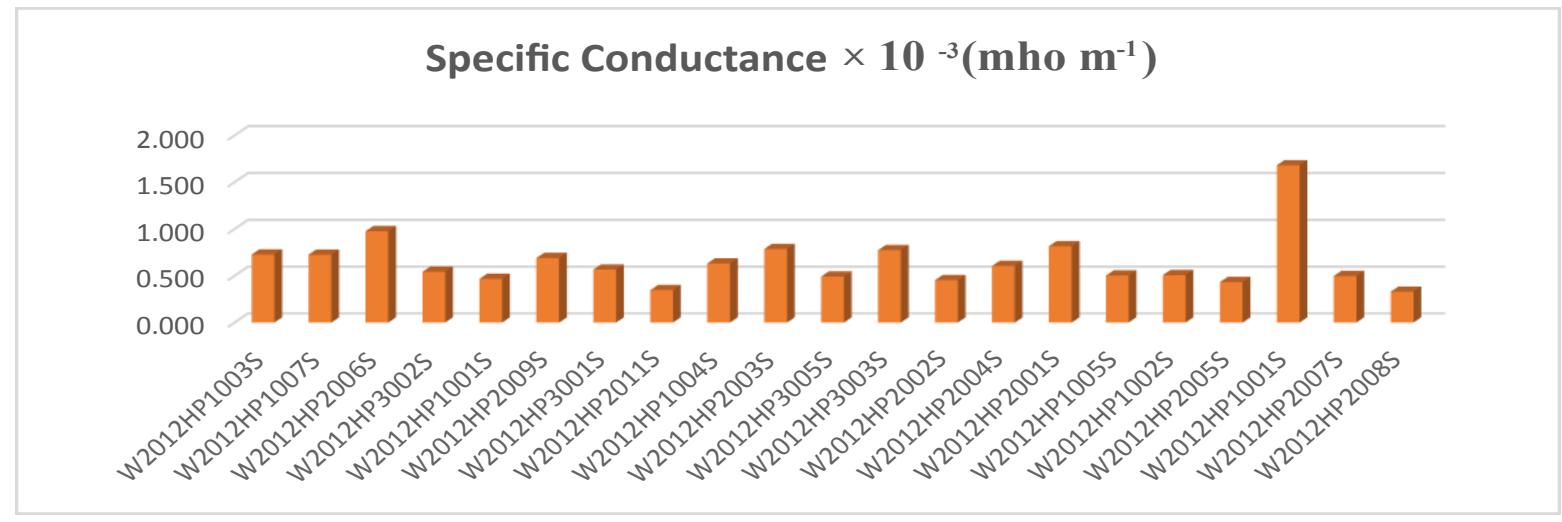

Figure 4: Specific conductance of water samples collected from different sampling points during summers.

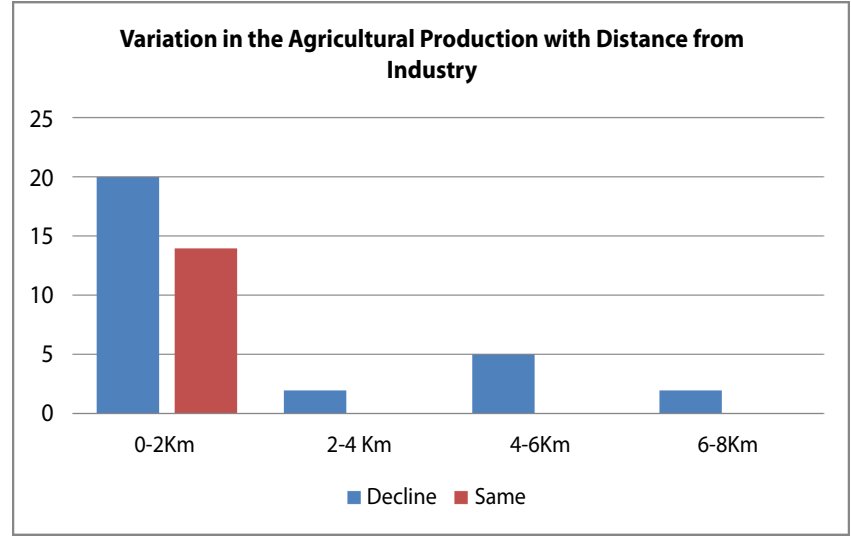

Figure 5: Variation of agricultural production with distance from industry in the study area.

\section{Variation of Water quality with Depth}

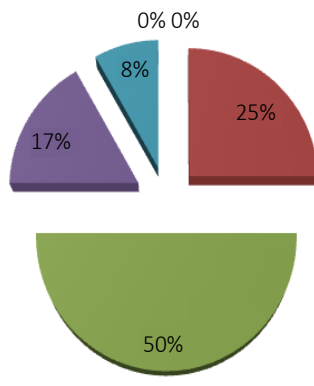

- $0-50$

- 51-100

101-150

-151-200

- 201-250

- 251-300

Figure 6: Variation of water quality with depth in the study area.

continuously decreasing, may be due to excessive utilization in industries and secondly it is getting polluted due to the industrial waste thrown in it which can be inferred from the views of villagers about the quality of water available there.

- People living near industries has experienced many health disorders in recent years like breathing problem, blood pressure, asthma, lungs problem, chest pain etc. Breathing problem is most commonly seen. Diseases like jaundice and cancer are rarely noticed.

\section{Variation of pollution in Agricultural Field with Distance from Industry}

-Decrease $\mathbf{n}$ Increase

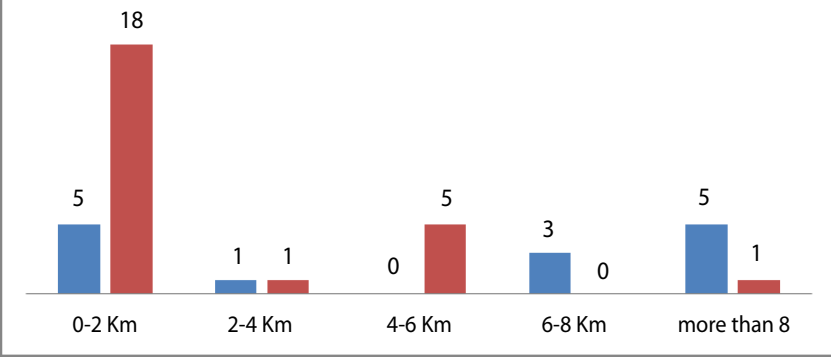

Figure 7: Variation of pollution in Agricultural field with distance from industry in the study area.

- Industrialization has its adverse effect on agriculture as well. Pollution in agriculture field has increased in recent years and is worst seen in the areas which is near to industries.

- As per the information provided by villagers, despite of the fact that the irrigation facilities have improved with the development of industries, agricultural productivity has not enhanced. It is same as before in Solan and Rupnagar but it has even declined in Una and Punchkula.

- Some new species have invaded after the setup of industries, mainly the birds like vulture, eagle, kite, crow etc. Pigs have also been reported in some areas.

\section{Conclusion}

The concentrations of heavy metal ions were observed to be higher in soils at the Rampur Jatan village. This implies that the activities that take place at the paper manufacturing industry has a major influence on the environment. The levels of these metal ions obtained in this environment may affect human health since the crops grown in this environment are continuously consumed. Thus, there is need for chemical/bioremediation of this environment and the suspension of all agricultural activities in this environment to avoid transmission of these metals to man through the food chain [27-30]. 
Citation: Sharma MC, Baxi S, Sharma KK, Singh M, Patel S (2014) Heavy Metal lons Levels and Related Physicochemical Parameters in Soils in The Vicinity of a Paper Industry Location in Nahan Area of Himachal Pradesh. J Environ Anal Toxicol 4: 236. doi: 10.4172/2161-0525.1000236
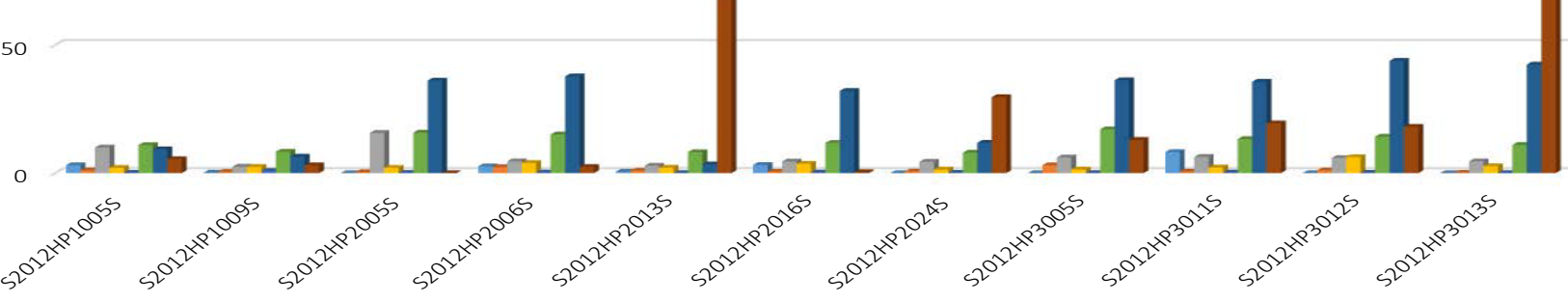

$\mathrm{Pb}=\mathrm{As}=\mathrm{Na}=\mathrm{Zn} \boxminus \mathrm{Cd} \equiv \mathrm{K}=\mathrm{Ca} \boxminus \mathrm{Cr}$

Figure 8: Concentration of metal ions in soil samples from different zones during summers.

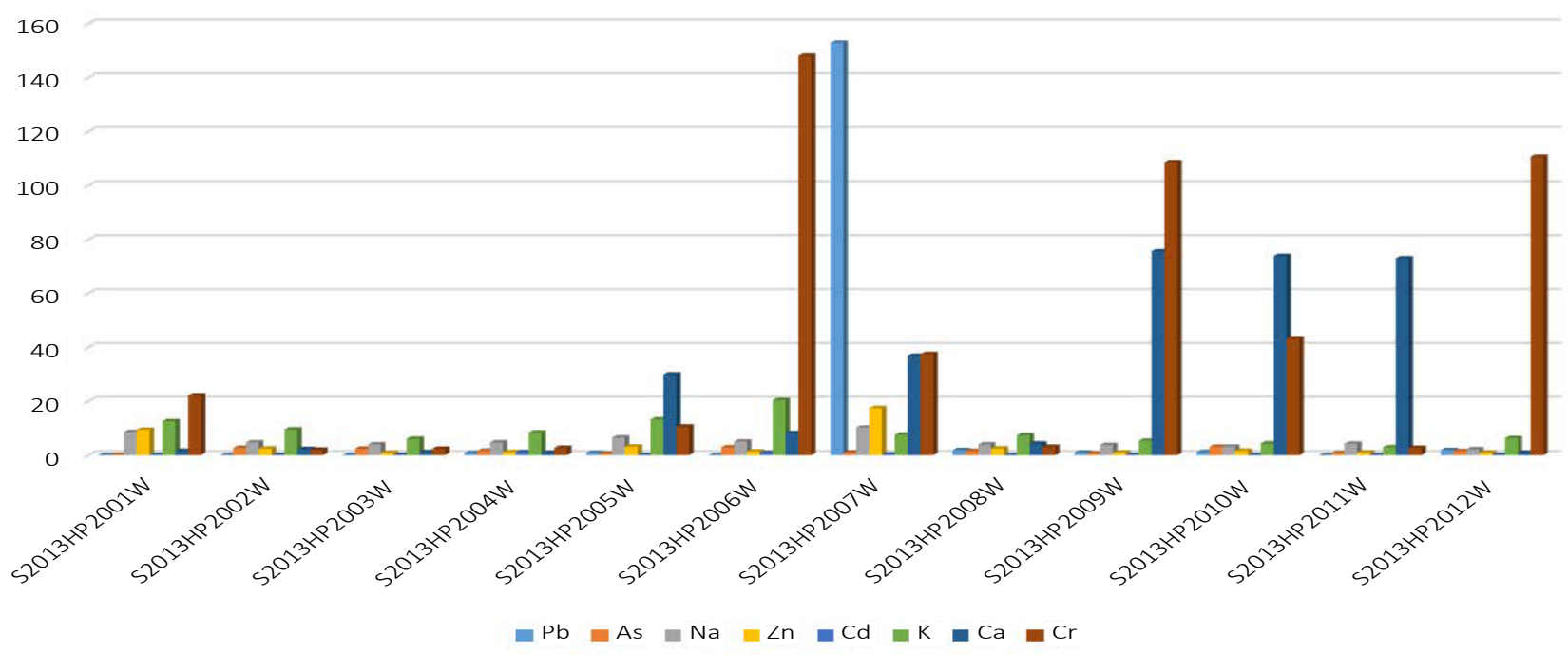

Figure 9: Concentration of metal ions in soil samples from different zones during winter season.

\section{Acknowledgement}

The authors are extremely thankful to University of Delhi for providing financial assistance in completing this project under the Innovation project scheme KMC 103.

\section{References}

1. Berthelsen BO, Steinnes E, Solberg W, Jingsen L (1995) Heavy meta concentrations in plants in relation to atmospheric heavy metal deposition. $J$ Environ Qual 24:1018-1026.

2. Chang AC, Warneke JE, Page AL, Lund LJ (1984) Accumulation of heavy metals in sewage sludge-treated soils. J Environ Qual 13: 87-91.
3. McBride MB (1995) Toxic metal accumulation from agricultural use of sludge: are USEPA regulations protective? J Environ Qual 24:5-18

4. Adebisi SA, Ipinromiti KO, Amoo IA (2007) Heavy Metals Contents of Effluents and Receiving Waters from Various Industrial Groups and their Environs. J Appl Sci 2: 345-348.

5. Lokhande RS, Singare PU, Pimple DS (2011) Quantification Study of Toxic Heavy Metals Pollutants in Sediment Samples Collected from Kasardi River Flowing along the Taloja Industrial Area of Mumbai India The New York Science Journal $4: 66-71$.

6. Kakulu SE, Abdullahi NK (2004) Impact of Municipal Solid Waste On Trace Metal Concentrations in Herbage and Soil Samples of the Abuja Municipality. Global J Environmental Sci 3: 65-69. 
Citation: Sharma MC, Baxi S, Sharma KK, Singh M, Patel S (2014) Heavy Metal lons Levels and Related Physicochemical Parameters in Soils in The Vicinity of a Paper Industry Location in Nahan Area of Himachal Pradesh. J Environ Anal Toxicol 4: 236. doi: 10.4172/2161-0525.1000236

7. Rajaram T, Das A (2008) Water pollution by industrial effluents in India discharge scenarios and case for participatory ecosystem specific local regulation Futures 40: $56-69$

8. Udosen ED, Udoessien El, Ibok UJ (1990) Evaluation of Some Metals in the Industrial Wastes from a Paint Industry and their Environmental Pollution Implications. Nigerian J Technol Res 2: 71-77.

9. Odiette WO (1999) Environmental Physiology of Animals and Pollution Diversified Resources Ltd Lagos 171-185.

10. Raven PH, Evert RF (1976) Biology of Plants $2^{\text {nd }}$ edn. Worth Publishers Inc New York 544

11. Akan JC, Abdulrahman FI, Dimari GA, Ogugbuaja VO (2008) Physicochemical determination of pollutants in wastewater and vegetable samples along the Jakara wastewater channelin kano metropolis, kano state, Nigeria European Journal of Scientific Research 23: 122-133.

12. Udosen ED, Obot NU, Bassey DE, Benson NU (2007) Phytoextraction Potential of Sporrobulus Pyramidalis found in an abandoned battery Industry Environment in Nigeria Tech and Environ Chem 89: 499-506.

13. Singare PU, Lokhande RS, Naik KU (2010) A Case Study of Some Lakes Located at and Around Thane City of Maharashtra India with Special Reference to Physico-Chemical Properties and Heavy Metal content of Lake Water Interdisciplinary. Environmental Review 11: 90-107.

14. USEPA Method 3051 (1994) A Test Methods for evaluating Solid Waste Physical/Chemical Methods $3^{\text {rd }}$ edition US Environmental Protection Agency Office of Solid Waste US Government Printing Office, Washington D.C.

15. ALPHA (1989) Standard methods for examination of water and wastewater 17 th (Eds) American Public Health Association, Washington DC.

16. Singare PU, Lokhande RS, Pathak PP (2010) Study on Physico-Chemical properties and Heavy Metal Content of the Soil Samples from Thane Creek of Maharashtra India Interdisciplinary. Environmental Review 11: 38-56.

17. Udosen ED, Ukpong EG, Asuquo JE, Etim EE (2012) Trace metal levels in soils and axonopus compressus within an Abandoned steel industry environment Research. Journal in Engineering and Applied Sciences 1: 64-69.

18. Oborn I, Modin-Edman, Bengtsson A, Gustafson H, Solomon GM, et al. (2005) A Systems Approach to Assess Farm-Scale Nutrient and Trace Element Dynamics A Case Study of the Ojebyn Dairy Farm. Ambio 34: 301-310.
19. Eka OU, Udotong IR (2003) A case study of Effects of Incessant Oil Spills from Mobil Producing Nigeria Unlimited on Human Health in Akwa lbom State. In: Adinna EN, Ekpo OB and Attah VI (Eds), Environmental Pollution and Management in the Tropics. Snaap Press Ltd. Enugu 219.

20. Joesten MD, Johnston DO, Netterville J, Wood JL (1991) World of Chemistry Saunders College Publishing Florida 301: 502.

21. Vincoli JW (1995) Basic Guide to Industrial Hygiene John Wiley and Sons Inc Canada 140-142.

22. Dara SS (1993) A textbook of environmental chemistry and pollution control S Chand \& Company Ltd Ram Nagar New Delhi.

23. Akesson A, Bjellerup P, Lundh T, Lidfeldt J, Nerbrand C, et al. (2006) Cadmium-Induced Effects on Bone In a population-Based study of Women. Environmental Health Perspectives 114 : 830-835.

24. Udoessien EI (2003) Basic Principles of Environmental Science for University and Allied Institutions Etiliew International Publishers Uyo 214.

25. Vecera ZP, Mikuska Z, Zdrahal B, Docekal M, Buckova Z, et al. (1999) Environmental Analytical Chemistry Department Institute of Analytical Chemistry Academy of Sciences of the Czech Republic Veveri 97: 611-42.

26. Ayodele JT, Gaya UM (1998) Chromium, Manganese and Zinc in Kano Municipality Street Dust. J Chem Soc of Nig 23: 24-31.

27. Adriano DC, Chlopecka A, Kaplan KI (1998) Role of soil chemistry in soil remediation and ecosystem conservation Soil Sci Soc Am Spec Public Madison WI 361-386.

28. Sharma MC, Saxena R, Sharma SK, Singh S (2009) Green approach of Chemical Immobilization of Lead in metal-Contaminated Soils of NCT of Delhi Using Coal Fly Ash. International Journal of Applied Chemistry 5: 63-71.

29. Sharma MC, Saxena R, Sharma SK, Singh S (2011) Modeling Of Heavy Metal Mobility In Delhi Soils Before and After Remediation With Rock Phosphate Using Sequential Extraction TCLP and PBET. Asian Journal of Water Environment and Pollution 8.

30. Sharma MC, Sharma SK (2012) Preconcentration and Remediation of Cadmium lons with Poly (Ethylene Imine) in Conjunction with Ultra - Filtration. Advances in Pure and Applied Chemistry 1: 2167-0854. 